\title{
Factors Affecting ODA Project Performance: The Case of Urban Railway Projects in Vietnam
}

\author{
Tran Dinh Nam ${ }^{1,2}$, Dang Ngọc Duc ${ }^{1} \&$ Nguyen Van Duy ${ }^{3}$ \\ ${ }^{1}$ National Economics University, Hanoi, Vietnam \\ ${ }^{2}$ Hanoi Metropolitan Railway Management Board, Hanoi, Vietnam \\ ${ }^{3}$ Viet Nam Quantitative Analysis Join Stock Company, Hanoi, Vietnam \\ Correspondence: Tran Dinh Nam, Organization \& Training Division - Hanoi Metropolitan Railway Management \\ Board, No. 8 Ho Xuan Huong Street, Hai Ba Trung District, Ha Noi City, Viet Nam. E-mail: \\ trandinhnam77@gmail.com
}

Received: August 16, 2016

doi:10.5539/ijef.v8n11p167
Accepted: September 29, $2016 \quad$ Online Published: October 25, 2016

URL: http://dx.doi.org/10.5539/ijef.v8n11p167

\begin{abstract}
This research aimed to develop and varify a model assessing factors affecting ODA project performance. The research adopted qualitative methods (one-on-one discussion, group discussion, 2-round expert network interview) to develop models and used quantitative methods (Cronbach Alpha test, EFA, CFA, and SEM) to varify the model. Research findings from 212 officers and staffs involved in urban railway projects in Vietnam showed that three factors among six factors that directly affected project performance were (1) management capacity; (2) adaptability and (3) financial capacity. Factors such as organization ability and risk management did not show an obvious influence on project performance.
\end{abstract}

Keywords: ODA, effective project management capacity, adaptability, financial capacity

\section{Introduction}

Official development assistance (ODA) plays an important role in socio-economic development of the less developed and developing countries. ODA is a source of additional investment funds, focusing on the development of basic infrastructure and other long-term development goals. Studies on the effectiveness of ODA utilization often focused on the assessment of its impacts on the economy (Hansen \& Tarp, 2001; Karras, 2006), studies in Vietnam often focused on attracting ODA for the development of industries or localities (Nguyen Ngoc $\mathrm{Vu}, 2010$; Ha Thi Thu, 2014). These studies were often specialized reports on assessment of ODA attration and utilization to devise solutions to attract ODA funds for industries or localities without focusing on the aspect of project management. Therefore, the current lack of studies that systematically assess factors affecting the performance in terms of project implementation. Therefore, this study was conducted to (1) establish a model and measurement indicators of project performance and influencing factors; (2) varify the model through research data in on-going urban railway projects in Hanoi.

\section{Research Overview}

\subsection{The Concept of ODA}

ODA began to take shape after World War II with the US Marshall Plan to assist allies. To the 1970s, United Nations General Assembly recommended the donor countries spend 0.7\% of their GNP as grant sources for poor and developing countries. Definitions of ODA may differ on the wording but are agreed on the fact that ODA is the development assisstance resources with at least $25 \%$ of non-repayable funds. For example, the World Bank (WB) defined "ODA is a part of official development finance with non-refundable factor plus concessional loan which accounts for at least $25 \%$ of total funding, then termed ODA" (WB, 2001). Thus, ODA can be seen as supporting funds for intergovernmental or transnational organizations, or foreign governments characterized by concessional and refundable or non-refundable, in which the non-refundable funds must account for at least $25 \%$.

\subsection{ODA Project Performance and Affecting Factors}

Performance is generally understood as the use of resources to achieve optimal goals. Research in business 
defined the concept of performance is to achieve strategic goals (Cyert \& March, 1992; Hult et al., 2004, Keh et al., 2007). Similarly, project performance can also be seen as the achievement of project goals. From the angle of project implementation, performance could be seen as the overall effectiveness of each component. Important issues of the project performance always are: (1) quality; (2) progress; (3) costs and (4) other objectives. Therefore, in this study we defined: "The performance of ODA fund utilization is to achieve objectives of all components involved in project implementation, achieve strategic objectives of each component in terms of quality of work, costs, schedule and other objectives."

There are a lot of factors that influence ODA project performance depending on diffent evaluation angles. From the angle of project implementation, there are six main factors affecting performance including (1) financial capacity; (2) organization capacity (3) operating capacity (4) adaptability and (5) risk management. In which:

Financial capacity: The ability in financial administration, creation of funds and financial flows to ensure works. Ensuring good financial capacity is an important factor affecting the performance results (Baral, 2005; Kouser et al., 2011).

Organization capacity: The ability to coordinate and combine implemtation activities to achieve the set objectives. The quality of organization and coordination is seen as a factor affecting implementation results (Becker \& Gerhart, 1996). Besides, the quality of activity connection may also affect performance outcomes (Walter et al., 2006).

Management capacity: Is the management ability of leaders over subordinate units. Leaders' good management inspires employees, creates links and control over work implementation. In relation to work implementation quality, management capacity has impacts on performance outcomes or the performance of the organization (Krasnikov \& Jayachandran, 2008).

Adaptability: The ability to organize and coordinate to re-format resources to meet environmental changes (Zahra et al., 2006; Zhou \& Li, 2010). Adaptability affects the viability and growth of the organization (Zhou \& $\mathrm{Li}, 2010)$.

Risk management capacity: Is the anticipation and response to the risks incurred during project implementation (Ward \& Chaman, 2003; Larson \& Gray, 2011). Project risk management can be done through the forecast of potential project mishaps, from which appropriate decisions are taken to avoid or minimize potential damages to the project.

\section{Research Methodology}

\subsection{Development of Research Models and Hypotheses}

To set up research model, the author used in-depth method by unstructured interviews (Suanders et al., 2007; Cresswell, 2009). The experts selected were esearchers and managers having participated in the research, management and implementation of ODA projects. Topics for discussion focused on two groups of aspects (1) the concept of ODA utilization performance in terms of management and (2) factors affecting project performance.

The results after conducting interviews with 10 different experts came to an agreement that in terms of management, project implementation performance is to achieve objectives set out in all components involved in the project regarding quality, schedule, cost, and other objectives. Regarding the group of factors affecting project implementation performance, experts have quite different opinions. After the assessment and screening, these can be aggregated into six main groups include: (1) financial capacity; (2) organization ability (3) management capacity (4) adaptability and (5) risk management. Research models were proposed as follows: 


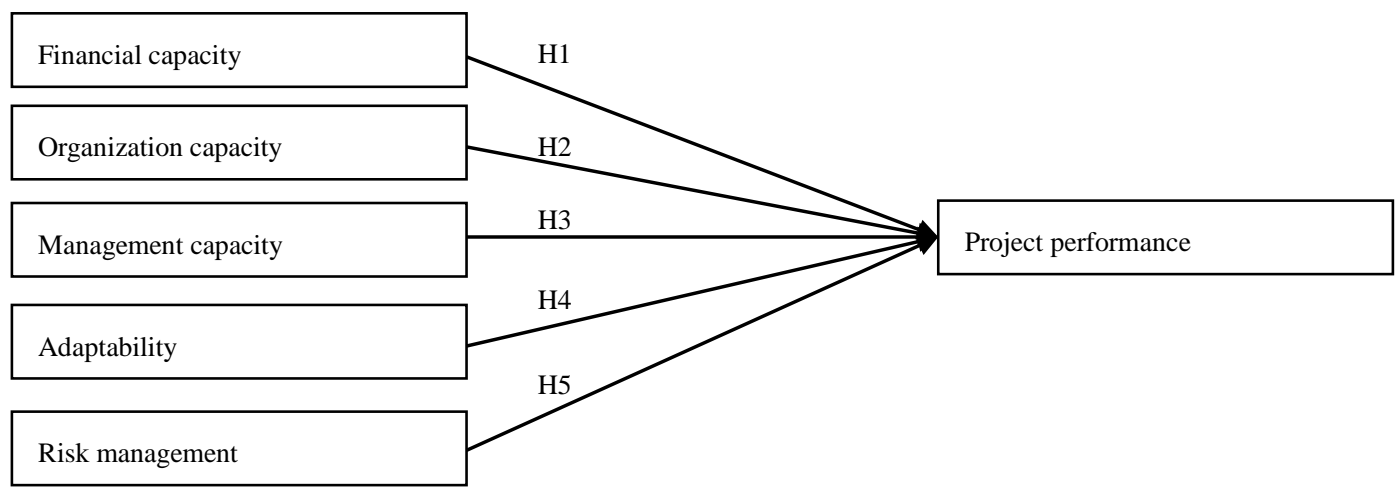

Figure 1. Research model

\section{Research hypothesis}

Financial capacity of the entities involved in the project in terms of administration capacity, creation of funds and financial flows for the implementation of relevant works. Ensuring good financial capacity showed effects on work performance results (Baral, 2005; Kouser et al., 2011). Therefore, this research proposed the hypothesis:

H1: Financial capacity factor had positive impacts on project performance.

Organization ability was the capacity regarding coordination and connection of activities to achieve set objectives. The quality of coordination and connection among activities showed impacts on performance results (Becker \& Gerhart, 1996; Walter et al., 2006). Therefore, this research proposed the hypothesis:

H2: The factor of organization ability had positive impacts on project implementation performance.

Management capacity was the inspiring, creating connection and control over the implementation of works directed from leaders. In relation to the work performance quality, management capacity had impacts on the performance results or the performance of organizations (Krasnikov \& Jayachandran, 2008). Therefore, this research proposed the hypothesis:

H3: The factor of management capacity had positive impacts on project performance.

Adaptability was the ability to coordinate and format resources to meet the changes of the external environment (Zahra et al., 2006; Zhou \& Li, 2010). For ODA projects, adaptability is the ability to manage when facing potential impacts on implementation quality, schedule and costs. In other words, good adaptability can improve project implementation. Therefore, this research proposed the hypothesis:

H4: Adaptability factor had positive impacts on project performance.

Risk management is the anticipation and response to potential risks during project implementation (Ward \& Chaman, 2003; Larson \& Gray, 2011). Good risk management ability could help engaged entities control work implementation even in case of incidents. Therefore, this research proposed the hypothesis:

H5: Risk management factor had positive impacts on project performance.

\subsection{Development of Scales}

To set up scales (observed variables) for each factor in the model we use various methods. First, semi-structured interviews with oriented questions were used. The research used both one-on-one discussion forms and focus group discussions. To obtain our first draft, we prepared a list of 20 experts who were able to participate in the study. Among which, 10 experts were expected to join discussions and 10 experts were spare for the event that some expert left the research or in case the interview with original experts did not reached "information breakpoint". Each expert was requested to offer up to three different aspects to evaluate a factor. Experts were in turns interviewed and the interview will stop when three consecutive experts did not add new aspects. This point was considered data saturation point. The results after screening overlapping opinions, irrational aspects we obtained initial draft questionnaire of 32 measurement indicators for the six factors in the model. This was followed by a group discussion with a group of 10 potential investigation objects for initial adjustment of semantic wording of questions.

Secondly, after having initial set of questions to assess the consistency of our measurement indicators, we used 
the assessment method of two- round expert network (Chu \& Hwang, 2008). Draft questionnaire was evaluated in terms of the level of importance of measurement indicators through a expert network consisting of 07 experts (taken from original 20 experts). These aspects were evaluated by a scale of 5 in which 1 was not important and 5 was very important in two different points of time for the same expert. The indicators retained must ensure a high level of importance through average assessment scores of experts (3.5) and the degree of opinion uniformity as well as the level of consistency among replies of the same expert (not exceeding 15\%). By the results after interviewing by two-round expert network, we collected 29 indicators to assess the factors in the model. In which:

Financial capacity factor of the entities involved in the project were evaluated through five observed variables including:

1). The unit having sufficient funds to execute project works.

2). Progress of funds transfer and disbursement to perform works up to the set plan.

3). Funds suppliers for the project always ensuring the safety level of project funding.

4). The unit being able to manage funds to carry out project-related tasks.

5). Always ensuring project liquidity when implementing project-related works.

The factor of organization ability were evaluated by five indicators, including:

1). Components coordinating well during project implementation.

2). Structures of project implementation components reasonably arranged.

3). Functions of each component implementing the project clearly described.

4). Procedures for works coordination during project implementation open and transparent.

5). Convenient work implementation process of the entity.

The factor of management capacity was assessed by six observed variables including:

1). Leaders in the entity being capable of inspiring employees.

2). Leaders in the entity capable of directing work implementation well.

$3)$. Leaders in the entity closely monitoring works.

4). Leaders always participating in solving problems during work implementation in the entity.

5). Leaders in the entity being capable of binding members.

6). Leaders in the entity always monitoring work results of each department.

Adaptability factor was evaluated by observing six variables included:

1). The entity always having coordination plans for ensuring work progress.

2). The entity having solutions to delayed disbursement.

3). The entity actively adjusting plans to match with each project implementation stage.

4). The entity being proactive when facing changes of mechanisms and policies during project implementation.

$5)$. The entity well coordinating with other when changes happened during project implementation process.

6). The unit being flexible to control work quality in his departments.

Factors of project risk management were evaluated by three observed variables include:

1). The entity having built scenarios of potential risks during project implementation.

2). Units having options to resolve problems during project implementation.

3). The unit having insurance policies for the implementation of project-related tasks.

Project performance was assessed by four observed variables include:

1). Components of works related to the entities during project implementation always ensuring implementation schedules.

2). The work quality of the entity related to the project implementation being always ensured good.

3). The implementation costs of project-related works of the unit not exceeding the estimate. 
4). In general, works related to the entity during project implementation process always achieving set objectives.

\subsection{Sampling and Data Collection Methods}

Investigation subjects of the research were the entities involved in two ong-going urban railway projects in Hanoi, i.e. Ha Dong - Cat Linh and Nhon - Hanoi Railway Station including management agencies and contractors (consultancy and construction). Identified sample size of 200 reached the level of moderate following the rule of Comrey and Lee (1992). We used investigation method by issuing printed questionnaires to potential respondents. The sample was divided into two phases: (1) the first phase to preliminarily assess the research scale, we investigated 100 samples; the second phase after turning away the invalid variables, we would continue to investigate full sample size. The result was that 250 questionaire notes were delivered at both stages, 212 valid notes were collected for formal analysis (Table 1):

Table 1. Research sample

\begin{tabular}{llc}
\hline & Classification criteria & No. of people investigated (percentage) \\
\hline \multirow{2}{*}{ Project } & Cat Linh - Ha Dong & $151(71.2 \%)$ \\
& Nhon - Hanoi Railway Station & $61(28.8 \%)$ \\
\hline \multirow{2}{*}{ Involved Divisions } & Project Management Units & $23(10.8 \%)$ \\
& Contractors & $189(89.2 \%)$ \\
\hline \multirow{2}{*}{ Position } & Indirect & $40(18.9 \%)$ \\
& Direct & $172(81.1 \%)$ \\
\hline
\end{tabular}

\subsection{Data Analysis Methods}

Sample size in the first phase $(\mathrm{n}=97)$ was preliminarily assessed by Cronbach Alpha coefficients, corrected item-total correlation and exploratory factor analysis with criteria as follows: Cronbach's alpha larger than 0.6 (Hair et al., 2006), the total variable correlation greater than 0.3 (Nunally \& Burstein, 1994); exploratory factor analysis with KMO larger than 0.5 , p-Bartlet test with p-value $<0.05$, explained variance larger than $50 \%$ (Hair et al., 2006). The analysis confirmed that factors were used to evaluate the convergence value, differentiated value and compatibility of the model with formal survey data. The research hypothesis was verified by analyzing the linear structure model at the significance level of 5\%. The model was seen as achieving compatibility as: Chi-square / df <3, CFI, TLI; IFI > 0.9, RMSEA <0.08 (Hair et al., 2006; Hooper et al., 2008; Kline, 2011). Weighting factors larger than 0.5 were considered convergence validity, the correlation between factors smaller than 1 was considered Discriminant Validity (Steekamp \& Van Trijp, 1991).

\section{Findings}

\subsection{Results of Preliminary Scale Assessment}

Analysis results with preliminary samples $(\mathrm{n}=97)$ showed that the research concept after eliminating variables with factor loading coefficient smaller than 0.3 had reached the necessary reliability (Cronbach Alpha coefficients greater than 0.6). Exploratory factor analysis indicated that scales were unidirectional and used exploratory factor analysis consistent with research data. KMO coefficients were larger than 0.5 , Bartlett's test had statistical significance, the total variance explained (TVE) was larger than 50\%, weighting factors were larger than 0.5 (Table 2):

Table 2. Preliminary assessment results of scales

\begin{tabular}{|c|c|c|c|c|c|}
\hline Factor & $\begin{array}{l}\text { Cronbach Alpha (no. } \\
\text { of observed variables) }\end{array}$ & $\begin{array}{c}\text { Smallest item-total } \\
\text { correlation }\end{array}$ & KMO & $\mathrm{p}$-value & $\operatorname{TVE}(\%)$ \\
\hline Financial capacity & $0.814(4)$ & 0.496 & 0.713 & 0.000 & $64 \%$ \\
\hline Organization ability & $0.896(5)$ & 0.656 & 0.855 & 0.000 & $71 \%$ \\
\hline Management capacity & $0.833(6)$ & 0.603 & 0.829 & 0.000 & $64 \%$ \\
\hline Adaptability & $0.845(4)$ & 0.513 & 0.782 & 0.000 & $69 \%$ \\
\hline Risk management & $0.751(3)$ & 0.482 & 0.657 & 0.000 & $63 \%$ \\
\hline Project performance & $0.816(4)$ & 0.510 & 0.733 & 0.000 & $65 \%$ \\
\hline
\end{tabular}




\subsection{Results of Scale Value Assessment}

Analysis of the ultimate model with official samples $(\mathrm{n}=212)$ obtaining the coefficients Chi-square/df $=1,873$ smaller than $3, \mathrm{CFI}=0.922$, TLI $=0.911$; IFI $=0.921$ larger than 0.9, RMSEA $=0.064$ smaller than 0.08 indicated that the model fitted with actual data. The weighting factors larger than 0.5 indicated that factors achieved convergence validity, the correlation between the variables smaller than 1 indicated that the factors were of discreminant validity. Total reliability larger than 0.7 and average variance extracted larger than $50 \%$ indicated the factors achieved necessary reliability (Table 3 ).

Table 3. Assessment results of scales

\begin{tabular}{lccccc}
\hline \multicolumn{1}{c}{ Factor } & No. of variables & Mean (Standard Deviation) & Range loadings & Total reliability & AVE \\
\hline Financial capacity & 4 & $3.336(0.840)$ & $0.693-0.904$ & 0.895 & $68 \%$ \\
Organization ability & 5 & $3.387(0.901)$ & $0.770-0.910$ & 0.917 & $69 \%$ \\
Management capacity & 6 & $3.490(0.793)$ & $0.706-0.825$ & 0.879 & $55 \%$ \\
Adaptability & 4 & $3.039(0.801)$ & $0.659-0.854$ & 0.856 & $60 \%$ \\
Risk management & 3 & $3.901(1.043)$ & $0.782-0.872$ & 0.856 & $66 \%$ \\
Project performance & 4 & $3.421(0.809)$ & $0.719-0.810$ & 0.839 & $57 \%$ \\
\hline
\end{tabular}

\subsection{The Results of Analysis by a Structural Model and Research Hypothesis Testing}

Analysis results by linear structural model showed that the model fitted the actual data: Chi - square / $\mathrm{df}=2.279$ $<3 ; \mathrm{CFI}=0.934 ; \mathrm{TLI}=0.921 ; \mathrm{IFI}=0.934$ larger than $0.9 ; \mathrm{RMSEA}=0.078$ smaller 0.08 (Figure 2).

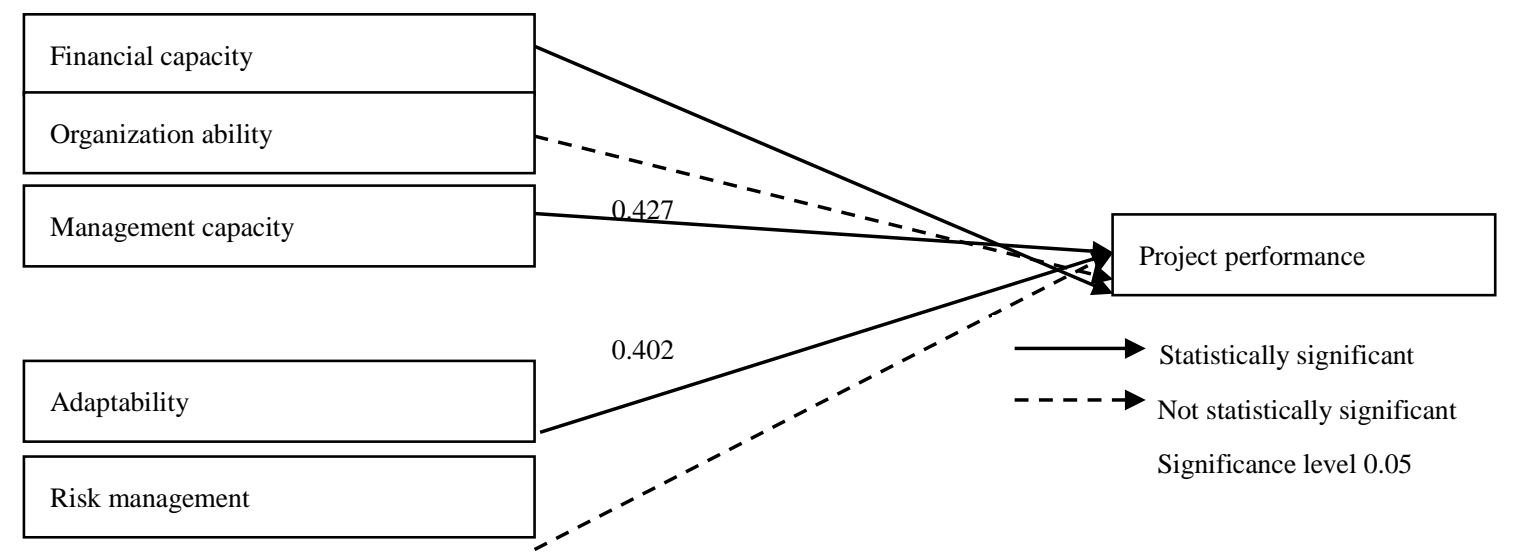

Figure 2. Analysis results of SEM model (standardized)

The estimation results showed that factors of financial capacity, management capacity and adaptability had positive impacts on project performance ( $\mathrm{p}$-value $<0.05$ ); The factor of organization ability, leadership vision, and risk management showed no impact on project performance (p-value> 0.05) (Table 4). In other words, accepted the hypothesis $\mathrm{H1}, \mathrm{H3}, \mathrm{H4}$, and rejected the hypothesis $\mathrm{H2}$ and $\mathrm{H5}$. Among the factors that affected project performance, management capacity factor had the greatest impact $\left(\beta_{\text {managementcapacity }}=0.427\right)$ followed by adaptability $\left(\beta_{\text {adaptability }}=0.402\right)$ and the factor of financial capacity had the lowest $\left(\beta_{\text {financialcapcity }}=0.267\right)($ Table 5$)$.

Table 4. Verification results of research hypotheses

\begin{tabular}{cllcccc}
\hline Hypothesis & & Variable relation & Standardized coefficient & p-value & Conclusion \\
\hline H1 & Financial capacity & $\longrightarrow$ & 0.267 & 0.000 & Accept \\
H2 & Organization capacity & $\longrightarrow$ & 0.028 & 0.774 & Reject \\
H3 & Management capacity & $\longrightarrow$ & 0.427 & 0.000 & Accept \\
H4 & Adaptability & $\longrightarrow$ Project performance & 0.402 & 0.000 & Accept \\
H5 & Risk management & $\longrightarrow$ Project performance & -0.028 & 0.734 & Reject \\
\hline
\end{tabular}




\section{Discussion and Research Implications}

Research developed and tested a model for assessing impacts of factors on ODA project performance in Vietnam. These concepts were developed and tested to show the reliability and value. This showed the relevance of the model in terms of both theory and empirical data. The measurement indicators were developed to provide criteria for evaluating operation capacity of stakeholders in project implementation. These scales can also help management agencies and researchers to measure, evaluate key factors affecting project performance, not only ODA projects.

Research results recorded three out of six factors included in the model having impacts on the project performance were (1) management capacity; (2) adaptability, and (3) financial capacity. This showed that during implementation phase, the completion of works under the project depended heavily on the management capacity of involved entities; adaptability to changes during implementation; and financial capacity of entities involved. Within the context of the project implementation phase, this is quite understandable. It is because during this stage, the ability to inspire, direct and closely follow the works, and participating in resolving difficulties encountered from subordinates, the ability to bind and regularly monitoring employees'results can help to monitor the progress, quality and control costs better. The entities involved during project implementation were always faced with uncertain risks. Therefore the ability to adapt, manage flexibly and quickly can help entities achieve goals. Financial capacity was also seen as an important factor in the implementation stage because money is necessary in all project-related works, Therefore, strong financial capacity of the units involved in projects could affect implementation progress and quality of works performed. These suggested that, for ODA projects during implementation stage, entities participating in the project from employers to contractors must pay attention to the management capacity, adaptability and strong financial capacity.

The research also noted that the performance of urban railway projects was assessed at low average level (3.42). Factors affecting project performance were not assessed at the highest score in terms of management capacity factor (3.49) and the lowest in adaptatability (3.03). This was quite consistent with the actual implementation status of urban railway projects in Hanoi today when all the projects are delayed in progress with a number of incidents occur during implementation, especially at Cat Linh - Ha Dong project funded by Chinese ODA and constructed by Chinese contractors. This information also required the Employer together with involved entities to focus on improving their management capacity when participating in the project.

Overall, this research has achieved its initial goals to develop and test a model to assess factors affecting ODA project performance during implementation phase. However, besides achieved results, there still remained weaknesses. Firstly, this was the first study to develop models and assessment scales for factors affecting project performance in Vietnam. Secondly, the sample size was relatively small in both research phases that could affect the generalizability of the research. Therefore, further studies could expand the sample size and continue finalizing and testing scales for the next study.

\section{References}

Australian Institute of Management. (2013). Australian Management Capability Index 2013. Canberra.

Baral, K. J. (2005). Health check up of commercial banks in the framework of CAMEL: A case study of Joint Venture Banks in Nepal. The Journal of Nepalese Business Sududies, 2(1), 41-55. http://dx.doi.org/10.3126/jnbs.v2i1.55

Becker, B., \& Gerhart, B. (1996). The impact of hunam resource management on organizatianl performance: Proress and prospects. The Academy of Management Journal, 39(4), 779-801. http://dx.doi.org/10.2307/256712

Chu, H. C., \& Hwang, G. J. (2008). A Delphi based approach to developing expert systems with the cooperation of multiple experts. Expert Systems with Applications, 34, 2826-2840. http://dx.doi.org/10.1016/j.eswa.2007.05.034

Comrey, A. L., \& Lee, H. B. (1992). A first course in factor analysis. Hilsdale, Erlbaun, New York.

Creswell, J. W. (2009). Research design: Qualitative, quantitative and mixed approaches (3th ed.). Los Angeles: Sage.

Cyert, R. M., \& March, J. G. (1992). A bahavioral theory of the firm (2nd ed.). Oxford: Basil Blackwell.

Ha, T. T. (2014). Attracting and using sources from official development assistance (ODA) to agriculture and rural development in Vietnam: A study in the Central Coast area ( $\mathrm{PhD}$ Thesis, University National Economics University). 
Hair, J. F., Black, W. C., Babin, B. J., Anderson, R. E., \& Tatham, R. L. (2006). Multivariate Data Analysis (6th ed.). Upper Saddle River NJ: Prentice -Hall.

Hansen, H., \& Tarp, F. (2001). Aid and growth regressions. Journal of Development Economics, 62(2), 547-570. http://dx.doi.org/10.1016/S0304-3878(00)00150-4

Hooper, D., Couglan, J., \& Mullen, M. R. (2008). Structural equation modelling: guidelines for determining model fit. Electronic Journal of Business Research Methods, 6(1), 53-60.

Hult, G. T. M., Hurney, R. F., \& Knight, G. A. (2004). Innovativeness: Its antecedents and impact on business $\begin{array}{llll}\text { performance. } & \text { Industrial } & \text { Marketing }\end{array}$ http://dx.doi.org/10.1016/j.indmarman.2003.08.015

Karras, G. (2006). Foreign aid and long run economic growth: Empirical evidence for a panel of devepoping countries. Journal of International Development, 18(1), 15-28. http://dx.doi.org/10.1002/jid.1187

Keh, H. T., Nguyen, T. T. M., \& Ng, H. P. (2007). The effects of entrepreneurial orientation and marketing information on the performance of SMEs. Journal of Business Venturing, 20, 592-611. http://dx.doi.org/10.1016/j.jbusvent.2006.05.003

Kline, R. B. (2011). Principles and practice of structural equation modeling ( $3 \mathrm{rd} \mathrm{ed})$. Guilford Press, Toronto.

Kouser, R., Mehvish, H., \& Azeem. (2011). CAMEL analysis for Islamic and conventional banks: Comparative study from Pakistan. Economics and Finnance Review, 10(1), 44-64.

Krasnikov, A., \& Jayachandran, S. (2008). The relative impact of marketing, research-and-development and operations capabilities on firm performance. Journal of Marketing, 72, 1-11. http://dx.doi.org/10.1509/jmkg.72.4.1

Larson, E., \& Gray, C. (2011). Project Management: The Managerial Process (5th ed.). NY: McGraw-Hill.

Nguyen, N. V. (2010). Some solutions to improve efficiency in the mobilization and utilization of ODA in Vietnam. The Journal of Science and Technology, 5(40), 305-311.

Nunally, J., \& Bernstein, I. (1994). Psychometric Theory (3rd ed.). New York: McGraw - Hill.

Steekamp, J. B. E. M., \& Van Trijp, H. C. M. (1991). The use LISREL in validating marketing construct.

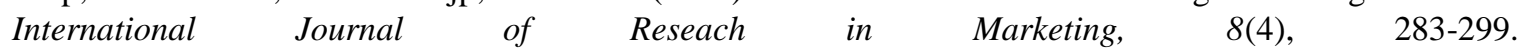
http://dx.doi.org/10.1016/0167-8116(91)90027-5

Suanders, M., Lewis, P., \& Thornhill, A. (2007). Research method for business students. England: Pearson Education Limited, Edinburgh Gate, Harlow, Essex CM202 JE.

Walter, A., Auer, M., \& Ritter, T. (2006). The impact of network capabilities and entrepreneurial orientation on university spin-off performance. Journal of Business Venturing, 21(4), 541-567. http://dx.doi.org/10.1016/j.jbusvent.2005.02.005

Ward, S., \& Chaman, C. (2003). Transforming project risk management into project uncertainty management. $\begin{array}{llll}\text { International Journal of Project } & \text { Management, } & \text { 21, }\end{array}$ http://dx.doi.org/10.1016/S0263-7863(01)00080-1

World Bank. (2001). Vietnam reported progress in the national supporting strategy of World Bank group from 2002 to 2003. Hanoi.

Zahra, S. A., Sapienza, H. J., \& Davidsson, P. (2006). Entrepreneurship and Dynamic Capabilities: A Review, Model and Research Agenda. Journal of Management Studies, 43(4), 917-955. http://dx.doi.org/10.1111/j.1467-6486.2006.00616.x

Zhou, K. Z., \& Li, C. B. (2010). How strategic orientation influence the buiding of dynamic capability emerging economies. Journal of Business Research, 63(3), 224-231. http://dx.doi.org/10.1016/j.jbusres.2009.03.003

\section{Copyrights}

Copyright for this article is retained by the author(s), with first publication rights granted to the journal.

This is an open-access article distributed under the terms and conditions of the Creative Commons Attribution license (http://creativecommons.org/licenses/by/4.0/). 